\title{
MLLT10/CLP1 Fusion Gene
}

National Cancer Institute

\section{Source}

National Cancer Institute. MLLT10/CLP1 Fusion Gene. NCI Thesaurus. Code C99570.

A fusion gene that results from a complex chromosomal rearrangement invins(10;11)

(p12;q23q12) which fuses the 5 ' end of the MLLT10 gene with the 3 ' end of the CLP1

gene. This chromosomal aberration is associated with acute monoblastic leukemia. 